Military Technical College Kobry El-Kobba

Cairo, Egypt

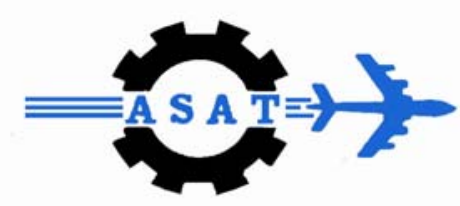

12-th International Conference on

Aerospace Sciences \& Aviation Technology

\title{
EXPERIMNTAL INVESTIGATION OF THE EFFECT OF USING DIESEL-METHANOL BLEND ON THE STEADY STATE PERFORMANCE OF DIESEL ENGINES
}

\author{
A. ABKAR*, A. EI MAIHY ${ }^{* *}$, A. RASHAD ${ }^{* *}$ and K. NASSERELDIEN ${ }^{* \star *}$
}

\begin{abstract}
In this work, an experimental investigation was conducted in order to study the effect of using methanol- diesel blends on the steady state performance of diesel engines. test rig was comprising a four stroke 5.67 liters, water-cooled diesel engine and a Heenan hydraulic dynamometer. Instrumentation included devices for measuring engine speed, load, exhaust gas temperature, NOx, in addition to fuel and air consumption rates. Tests were carried out on the engine when running with diesel fuel first, and then with methanol- diesel blends at different methanol concentrations, namely $2.5,5$ and $15 \%$ by volume. The results showed that methanol concentration has no effect on exhaust temperature, while NOx formation was affected by methanol concentration in the fuel blend. This effect was limited to $2.5 \%$ methanol concentration by volume.
\end{abstract}

Key words: Alternative fuels - Methanol/ diesel fuel blend - NOx emissions

\section{NOTATION}

$\begin{array}{ll}\text { BSFC } & \text { Brake specific fuel consumption } \\ \text { BMEP }(\mathrm{Pb}) & \text { Brake mean effective pressure } \\ \text { EGR } & \text { Exhaust gas recirculation } \\ \mathrm{Ne} & \text { Effective power } \\ \text { Tex } & \text { Exhaust gases temperature } \\ \text { NOx } & \text { Nitric oxides }\end{array}$

\footnotetext{
* Sudanese $\mathrm{PhD}$ student

** Egyptian Armed Forces

*** Assoc. Proff. in Khartoum university, Sudan
} 


\section{INTRODUCTION}

Diesel engines enjoy better fuel economy, compared to petrol engines, especially at part load. This has lead to the wide spread application of diesel engines in heavy duty trucks and power generating units. At present, engine designers are faced with the increasing demands for improved fuel consumption and lower exhaust emission. It is difficult to simultaneously reduce $\mathrm{NO}_{x}$ and smoke in Conventional diesel engine due to the trade-off curve between $\mathrm{NO}_{x}$ and smoke [1]. A better understanding of the formation of Nitrogen oxides has been gained, and that knowledge has led to the development of some innovative control technologies for Nitrogen oxides [2]. The seven oxides of Nitrogen that are known to occur are $\mathrm{NO}, \mathrm{NO}_{2}, \mathrm{NO}_{3}, \mathrm{~N} 2 \mathrm{O}, \mathrm{N}_{2} \mathrm{O}_{3}$, $\mathrm{N}_{2} \mathrm{O}_{4}$ and $\mathrm{N}_{2} \mathrm{O}_{5}$. Of these oxides of Nitrogen, $\mathrm{NO}$ (Nitric oxide) and $\mathrm{NO}_{2}$ (Nitrogen dioxide) are the two most important air pollutants because they are emitted in large quantities. The term "NO${ }_{x}$ " can refer to all of the oxides of nitrogen, but in air pollution work $\mathrm{NO}_{x}$ generally refers only to $\mathrm{NO}$ and $\mathrm{NO}_{2}$. Nitrogen oxides are emitted in the United States alone at a rate of about 20 million metric tons per year, about $40 \%$ of which is emitted from mobile sources (automobiles, trucks, buses, and so forth). Nitric oxides are formed by either or both of two mechanisms, thermal $\mathrm{NO}_{\mathrm{x}}$ or fuel $\mathrm{NO}_{\mathrm{x}}$. Thermal $\mathrm{NO}_{\mathrm{x}}$ is formed by the reactions between Nitrogen and Oxygen in the air used for combustion. The rate of formation of thermal $\mathrm{NO}_{x}$ is extremely temperature sensitive, and becomes rapid only at flame temperatures (3000-3600 F). Fuel $\mathrm{NO}_{\mathrm{x}}$ results from the combustion of fuels that contain organic Nitrogen in the fuel (primarily coal or heavy oil). Fuel $\mathrm{NO}_{x}$ formation is dependent on local combustion conditions (Oxygen concentration and mixing patterns) and on the Nitrogen content of the fuel. Successful control of $\mathrm{NO}_{\mathrm{x}}$ depends on an understanding of the fundamental principles of $\mathrm{NO}_{x}$ formation. One prospective method to solve this problem is to use oxygenated alternative fuel or to add the oxygenated fuels in diesel to provide more oxygen during combustion [3].

Fayed [5] studied the effect of fumigated Methanol on a single cylinder engine performance and combustion characteristics at engine part load. He concluded that fumigated Methanol increases the engine power at 50\%: $70 \%$ rack position and slightly improves the BSFC. The combustion roughness and cylinder peak pressure increased with increasing Methanol content. Murayama et al [6] studied the emission and combustion with EGR and Dimethyl ether. Miyamoto et al [7] and Akasaka and Sakwai [8] also conducted research on diesel combustion improvement and emission reduction by the use of various oxygenated fuel blends.

Methanol is regarded as one of the promising alternative fuels for diesel engines with its advantages of high Oxygen content. However due to the difficulty in forming a stabilized diesel/Methanol blends, few reports were found on this topic, and previous work was mainly concentrated on the application of diesel/methanol blends in a compression ignition engine $[9,10]$. Therefore, extra work is needed on the application of diesel/Methanol blends in a compression ignition engines to clarify the basic combustion and emission characteristics, and to provide an approach for attaining a stabilized diesel/methanol blend with/without solvent.

The objective of this work is to study the effect of Methanol content in diesel fuel blends on the steady state performance and NOx emissions of a direct injection diesel engine. The stabilized blend was prepared by using a mechanical stirrer ( explained latter). 


\section{2- EXPERIMENTAL SETUP}

\subsection{THE TEST FACILITY}

The test rig includes the engine and all the instrumentation necessary for measuring and recording operating parameters. An on-line data acquisition system was furnished to improve the speed and accuracy of data collection and recording. Figure 1 shows the layout of the experimental set-up present in the engine laboratory of the Department of Mechanical Power and Energy at the Military Technical College. A transport diesel engine of type Mercedes-Benz with an open chamber was used, detailed engine specifications are given in appendix (A).

The Methanol-diesel blend was prepared in a special supply with an impeller driven by an electric motor. The latter was operated continuously during tests to insure intimate mixing of the Methanol and fuel. The homogeneity of the Methanol/fuel blend was periodically checked at the entrance of the fuel injection pump.

Engine external loading was carried out by an ELZE /Heenan hydraulic dynamometer. The fluid used is water with which the maximum braking power could reach $170 \mathrm{~kW}$ at $4000 \mathrm{rpm}$.. The engine and dynamometer shafts were directly coupled through a cardan shaft. The air flow rate was calculated from the orifice area and the manometer reading. The Engine fuel consumption at steady state operation was evaluated by recording the time of consumption of a certain volume of fuel. The measuring device consisted of a glass flask of $80 \mathrm{cc}$ volume, an auxiliary fuel tank, control cock and a stop watch. The large air surge tank mounted upstream the air filter insured negligible fluctuations of the pressure. A thermocouple of type $\mathrm{K}(\mathrm{NiCr}-$ $\mathrm{Ni}$ ), with a special multichannel amplifier was used to measure the temperature of the exhaust gases.

$\begin{array}{cc}\text { and the Parameter Measured at Each } \\ \frac{\text { Location }}{1} & \frac{\text { (Relevant to Fig. 1) }}{\text { Measured Parameter }} \\ 2 & \frac{\text { Engine speed }}{\text { Dynamometer reading }} \\ 3 & \text { Inlet air flow rate } \\ 4 & \text { NOx measurement } \\ 5 & \text { Fuel flow rate } \\ 6 & \text { Exhaust gas temperature }\end{array}$

\subsection{FUEL BLENDS}

Three kinds of diesel methanol blends with different methanol concentration namely 2.5, 5, $15 \%$ by volume were used for the study. Due to low solubility of the methanol in diesel fuel, the fuel blends were mechanically prepared using an impeller of a centrifugal pump, which rotates continuously during each test. The blend is tested at the inlet of the injectors many times to insure that no separation between the two fuels occurs. Fuel properties and the constituents of the three blends are given in Appendices B and C.

\subsection{THE TEST CONDITIONS}

The experimental program was carried out so that the data obtained would give a full display of the engine performance under different operating conditions. The test parameters included : brake power, fuel consumption and air flow rates, exhaust temperature, and in-cylinder pressure. The fuel employed was diesel oil with $0,2.5$, 5 , and $15 \%$ by volume methanol content. These parameters were measured at different loads $(0,15,25,30,40$ dynamometer readings) and different speeds (700, $1100,1500,1900,2300 \mathrm{rpm})$. 


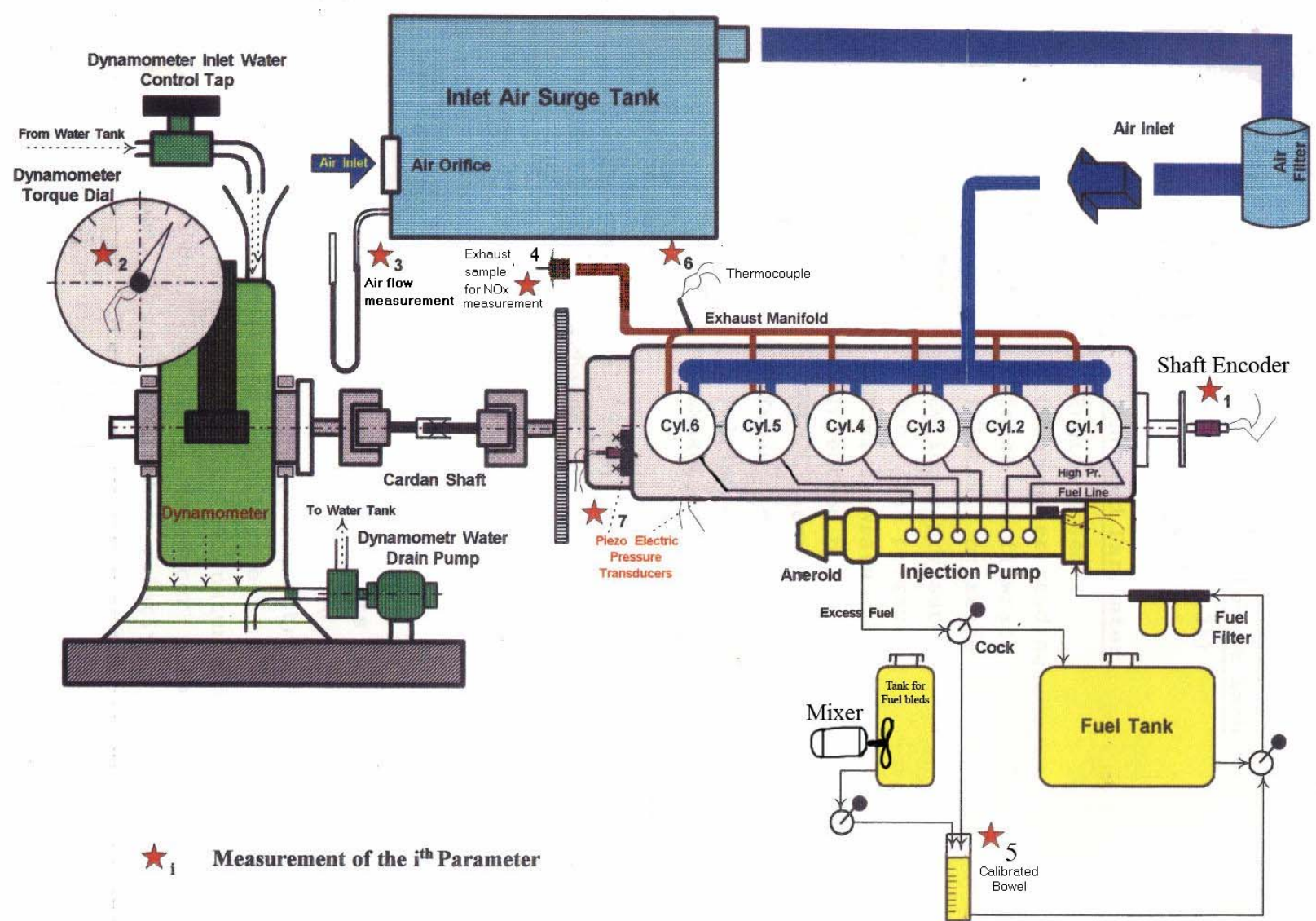

Fig.1. Schematic Drawing of the Test Rig 
The engine characteristics that were drawn from the experimentally obtained data are briefly presented in the following sections.

\section{RESULTS AND DISCUSSION}

\subsection{Engine Overall Speed Characteristics}

Fig. 2 shows the speed characteristics of the diesel engine with $15 \%$ of Methanol in diesel oil by volume. Performance curves are presented at 5 fixed external loads, namely $0.0,2.33,3.89,4.67$, and 6.22 bar Brake Mean Effective Pressure (Pb) in preference of brake torque. The results at each load are plotted against engine speed.

Exhaust gas temperature is shown to increase with engine speed and load. The effect is explained by the less amount of heat transferred to cylinder walls as engine speed increases, and hence more heat is carried away with exhaust. The effect of increased load is a direct result of the more fuel injected and consequently more heat evolved during the combustion processes.

The engine power is a direct function of engine speed and brake mean effective pressure $(\mathrm{Pb})$. This is clear from the linear dependence on speed drawn at fixed $\mathrm{Pb}$.

The brake specific fuel consumption (BSFC) is shown to have an increasing trend with the increase in engine speed. This is attributed to the higher friction losses at higher engine speed. The trend is however different at small loads and small speeds due to poor mixing of air and fuel. The BSFC is shown to decrease with engine load due to the increase in mechanical efficiency.

The mixture equivalence ratio increases with the brake mean effective pressure. This is due to the greater amount of fuel injected when higher loads are required. The effect of higher speed is attributed to the better pump efficiency.

NOx is shown to increase with load and speed. This may be attributed to the less amount of heat transferred to cylinder walls as engine speed increases, and hence more heat is available to increase the cylinder maximum temperature which is the major factor of NOx formation. The increased load means more fuel injection and consequently more heat evolved during the combustion processes.

The engine overall speed characteristics shows the same trends for various methanol contents in diesel oil namely $0,2.5,5$ and $10 \%$ by volume. The effect of the percentage of methanol content will be presented in the following section.

\subsection{Effect Of Methanol Content In Diesel Oil On Engine Performance}

Figures (3 to 7) show the variation of engine performance parameters with the percentage of methanol content in fuel blend $(0,2.5,5,15 \%)$ at different BMEP, namely $(0.0,2.33,3.69,4.66$, and 6.22 bar $)$ at three different speeds namely 700 , 1500 and $2300 \mathrm{rpm}$.

The effect of methanol content on the BSFC is shown in figure (3). The BSFC is shown to increase as the methanol content in the fuel blend increases until $5 \%$ by volume under different engine speeds. This effect may be explained by the increased heat of evaporation when adding more Methanol, this heat is extracted from the compressed air causing drop in its temperature. Besides, the decrease in the heating value of the fuel blend as methanol content increases. Both result in the need of injecting more fuel to produce the same BMEP. The BSFC is shown to decrease at $15 \%$ methanol in the fuel blend this attributes to the significant increase in the delay period that leads to more fuel to be burnt in the premixed burning phase and results in an improvement in thermal efficiency as shown in figure (4). Since the thermal 
efficiency is inversely proportional to the BSFC they must reflect the same phenomenon but present opposite trends in their curves.
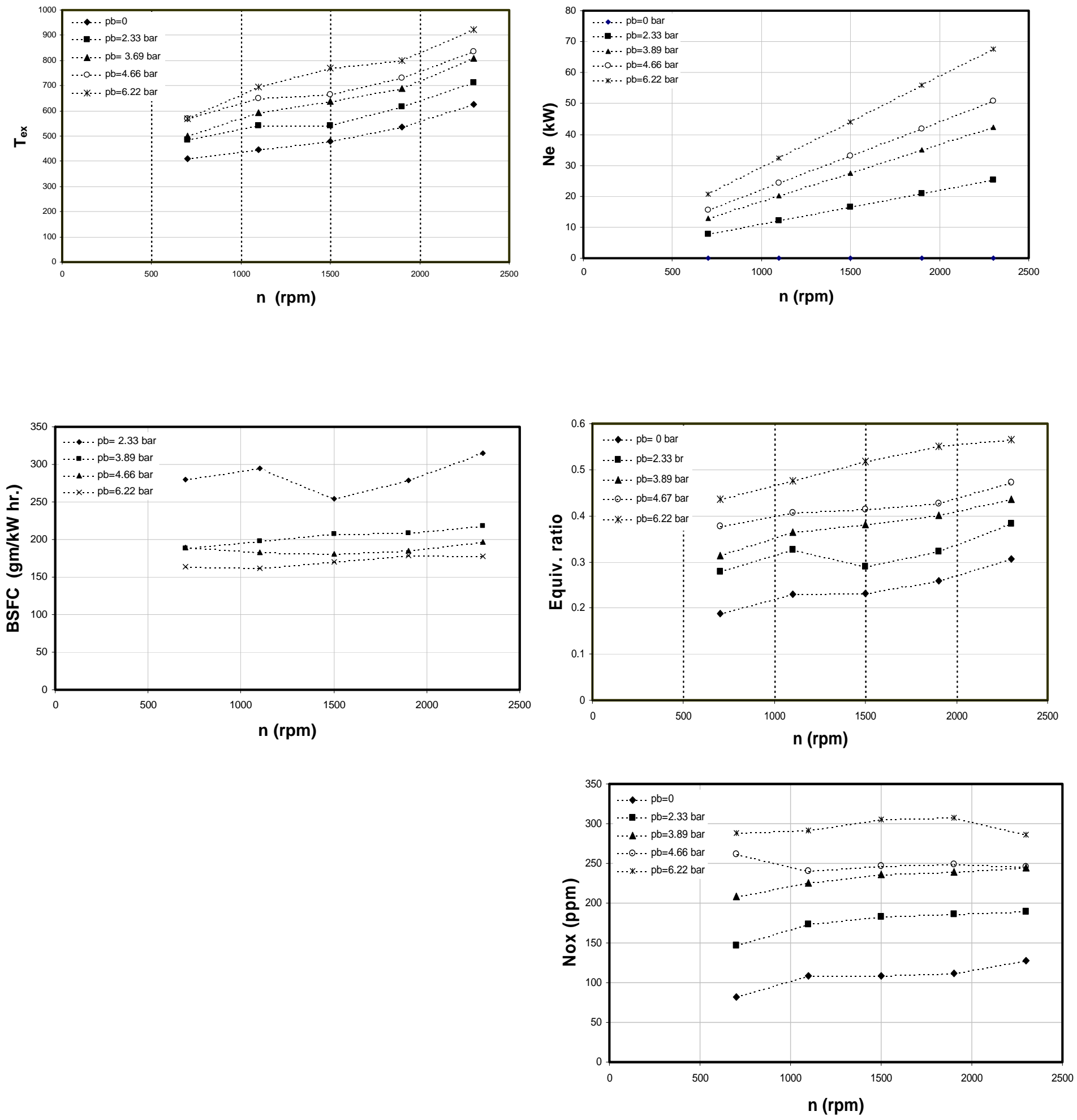

Fig. 2. Overall speed characteristics of diesel engine at Methanol content $15 \%$ by volume at different BMEP $\left(P_{b}\right)$ 
Figure (5) shows the effect of methanol concentration on the exhaust temperature. The figure shows that the exhaust temperature is not affected by methanol concentration in the fuel blend. This can be explained as follows: when using fuel blend the ignition timing is retarded due increased self ignition temperature of the fuel blend (the self ignition temperature of methanol is higher than that of diesel fuel), this leads to higher temperature at ignition point. The temperature after combustion is supposed to increase. On the other hand there are two conflicting effects: first, more energy is extracted from the compressed air to burn the fuel blend (to overcome the energy barrier) which decreases the compressed air temperature [1]. Secondly, the energy content in the fuel blend (heating value) is less than the energy content in diesel fuel and thus the heat released during combustion could be decreased. The exhaust temperature therefore would nearly remains unchanged.

Figure (6) shows that at all engine speeds when increasing the methanol percentage to $2.5 \%$ the amount of $\mathrm{NO}_{\mathrm{x}}$ decreases. This may be explained as follows: the self ignition temperature of fuel blend is higher than that of pure fuel because of methanol. The ignition point of of fuel blend is retarded until the temperature of the compressed air reaches the self ignition temperature of the fuel blend. The temperature after combustion is lower due to the decreased heating value of the fuel blend and hence less amount of thermal $\mathrm{NO}_{\mathrm{x}}$ is formed. Also, the time of residence of Oxygen and air Nitrogen at high temperature after the beginning of combustion is reduced causing low $\mathrm{NO}_{\mathrm{x}}$ emission. The figure shows also that for methanol concentration more than $2.5 \%$ that effect is approximately constant. This is attributed to the lower heating value of the fuel blend which decreases more as the percentage of methanol content increases.

\section{CONCLUSION}

A blend of diesel/methanol was used with concentration of $2.5,5$, and $15 \%$ of methanol by volume is tested experimentally on a direct injection diesel engine. The results show that the specific fuel consumption increases with the concentration of methanol mostly due to the decreased heating value of the blend and hence the thermal efficiency.

The exhaust temperature was found to be unaffected by the concentration of methanol and this attributes to two opposed effects: first reduction of the heating value of the fuel blend and secondly increasing the compressed air temperature before combustion.

Finally, it was found that the amount of $\mathrm{NO}_{\mathrm{x}}$ formed decreases with higher methanol concentration in the fuel blend. This reduction may be due to the drop in temperature after combustion and shorten time of residence of air. 

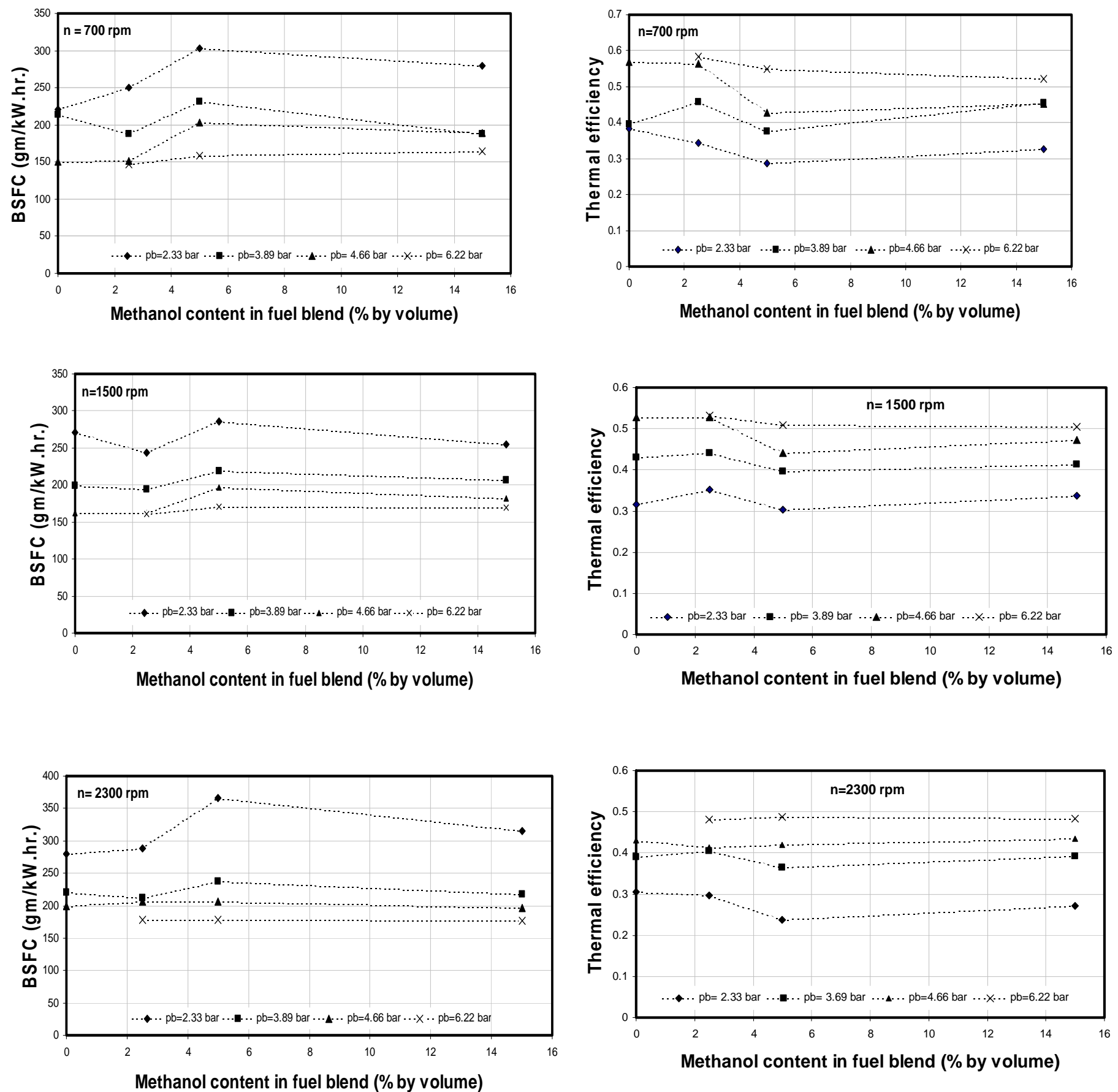

Fig.3. Effect of Methanol content in fuel blend on the BSFC at different BMEP and various sneerls

Fig.4. Effect of Methanol content in fuel blend on the thermal efficiency at different BMEP and various speeds 

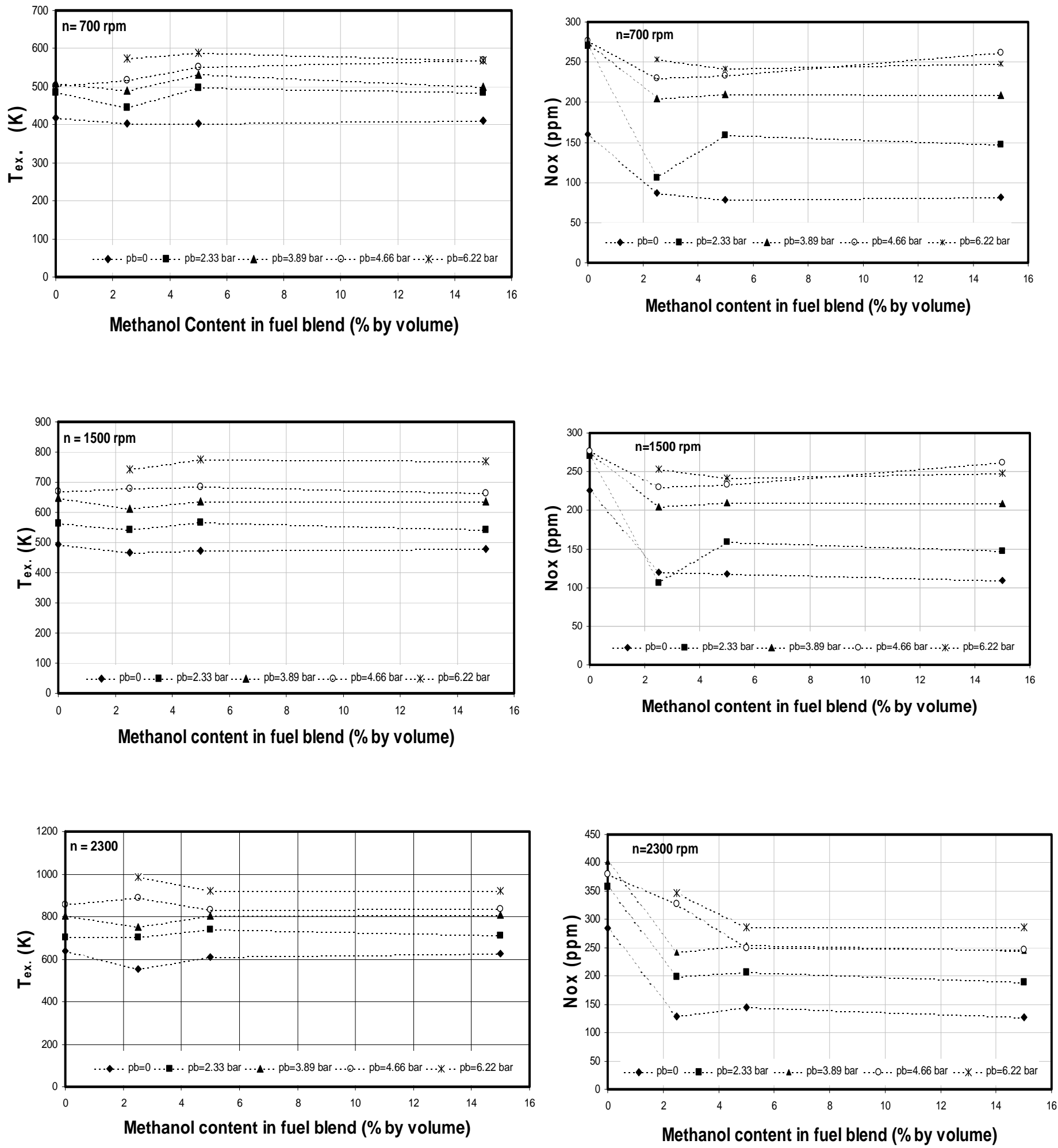

Fig.5. Effect of Methanol content in fuel blend on the exhaust temperature at different BMEP and various speed

Fig.6. Effect of Methanol content in fuel blend on NOx at different BMEP and various speed 


\title{
5. REFERENCES
}

1- Huang, Z. H., Lu., Jiang, D. M., Zeng, K., Liu, B., Zhang, J.Q. and Wang, X.B. Combustion behaviours $f$ a compression-ignition engine with diesel/methanol blends under various fuel delivery advance angles". Bioresourses Technology 95 (2004) 331-341/

2- Cooper, C. D,, Alley, F.C. "Air Pollution control" A Design Approach. $2^{\text {nd }}$ Edition, Waveland press, Inc., Illinois, 1994.

3- Huang, Z. H., Lu., Jiang, D. M., Liu, B., Zhang, J.Q. and Wang, X.B. "Engine Performance and emissions of a compression ignition engine operating on dieselmethanol blends". Proc. Instn. Mech. Engrs Vol. 218 Part D. J. Automobile Engineering. I Mech E 2004.

4- Heywood, J. B. "Internal Combustion Engine fundamental", McGRAW- HILL INTERNATIONAL EDDITION, 1988.

5- Fayed, M. A. " Effect of Methyl alcohol fumigation on performance and combustion characteristics of diesel engines at part loads" Msc. Thesis, Military Technical College, Cairo 1989.

6- Murayama, T., Zheng, M. and Chikahisa, T." Simultaneous reduction of smoke and Nox from a DI diesel engine with EGR and dimethyl carbonate. "SAE paper 952518, 1995.

7- Miyanoto,N., Ogawa, H. and Obata,K." Improvement of diesel combustion and emissions by addition of oxygenated agents to diesel fuels: influence of properties of diesel fuels and kinds of oxygenated agents.JSAE Rev., 1998, 19(2), 154-156.

8- Akasaka, Y. and Sakurai, Y." Effect of oxygenated fuel on exhaust emission from DI diesel engines" Trans. Japan Soc. Mech. Engrs. Ser. B, 1996, 63(609), 18331839.

9- Ali, Y., Hanna, M.A., Borg, J.E." Optimization of diesel, methyl tallowate and ethanol blend for reducing emissions from diesel engine" Bioresource Technology $52,1996,237-243$.

10-Stage de Caro,P., Mouloungui,E., Vaitillingom,G., Berge,J.C." Interest of combining an additive with diesel -ethanol blends for use in diesel engines" Fuel $80,2001,565-574$.

\author{
Appendix A \\ Engine Technical Data \\ Make and Model \\ Mercedes 352 series
}




$\begin{array}{ll} & \text { Natural aspirated } \\ & \text { Diesel engine } \\ \text { Compression ratio } & 17: 1 \\ \text { No. of Strokes } & 4 \\ \text { No. of cylinder } & 6 \\ \text { Arranging } & \text { In-line } \\ \text { Cooling } & \text { Water } \\ \text { Bore } & 97 \mathrm{~mm} \\ \text { Stroke } & 128 \mathrm{~mm} \\ \text { Combustion chamber } & \text { Open type, Direct Injection } \\ \text { Cam shaft } & \text { Sided } \\ \text { Speed range } & 800-2800 \mathrm{rpm} \\ \text { Maximum power } & 120 \mathrm{HP} \text { at 2800 rpm } \\ \text { Maximum torque } & 28 \mathrm{kp} . \mathrm{m} \text { at } 1600 \mathrm{rpm} \\ \text { Static injection } & 23 \mathrm{CA} \text { BTDC } \\ \text { Firing order } & 1536241 \\ \text { Min. compression pressure } & 20 \text { bar at } 150-200 \mathrm{rpm} \\ \text { Injector opening pressure } & 200 \text { bar }\end{array}$

Chemical formula

Molecular mass

Density $\left(\mathrm{kg} / \mathrm{m}^{3}\right)$

Lower heating value $(\mathrm{kJ} / \mathrm{kg})$

Self ignition temperature $\left({ }^{\circ} \mathrm{C}\right)$

Cetane number

Carbon content \%

Hydrogen content \%

Oxygen content \%

Blended fuel 1 wt $\%$

Blended fuel 2 wt $\%$

Blended fuel $3 \mathrm{wt} \%$

Heat of evaporation $(\mathrm{kJ} / \mathrm{kg})$

\section{Appendix B}

Properties of base fuel (gas oil) and Methanol

Base fuel (gas oil)

$\mathrm{C}_{10.8} \mathrm{H}_{18.7}$

148.3

0.84

42.5

$200: 220$

48

$87 \%$

$12.6 \%$

$0.4 \%$

$97.65 \%$

$95.28 \%$

$85.5 \%$

260
Methanol

$\mathrm{CH}_{3} \mathrm{OH}$

32

0.79

19.7 470

5

$37.5 \%$

$12.5 \%$

$5 \%$

$2.35 \%$

$4.72 \%$

$14.2 \%$

1110

\section{Appendix C \\ Properties of gas oil - Methanol blends \\ Blended fuel 1 \\ Blended fuel 2}

Density $\left(\mathrm{kg} / \mathrm{m}^{3}\right)$

Lower heating value $(\mathrm{kJ} / \mathrm{kg})$

Heat of evaporation( $\mathrm{kJ} / \mathrm{kg}$ )

Cetane No.
0.8388

41.96

279.975

46.9
0.8376

41.42

300.12

45.9
Blended fuel 3

0.8329

39.26

380.7

41.9 